\title{
A STUDY ON UTILIZATION OF CHINA'S BONDED AREA FOR EXPANDING AGRIFOOD EXPORT OF KOREA
}

\author{
Chang-Hwan Yü, Byung-Sam Yoon², Myagmarsuren Ukhnaa ${ }^{3}$,Shun-Bo Yao ${ }^{4 *}$ \\ ${ }^{I}$ RDA Farm \& Agriculture Exports Division, Jeonju Korea \\ ${ }^{2}$ Department of Agriculture Economics, Chungbuk University College, Korea \\ ${ }^{3}$ Department of Management, Mongolia National University Business school, Mongolia \\ ${ }^{4}$ Department of Economics and Management, Northwest A\&F University, yangling, People's Republic of China \\ *corresponding author,mail: yaoshunbo@nwsuaf.edu.cn
}

ARTICLE INFO: Received: 10 Nov, 2017; Revised: 19 Dec, 2017; Accepted: 22 Dec, 2017

\begin{abstract}
China is showing trends of increase in international trade due to worldwide economic growth. Furthermore, the annual increases in trade value of its bonded area, Bonded logistics complex, etc. are greatly contributing to the development of China's commerce as result of rising demands from foreign markets. Bonded area is favorable to trade environment and it is typically installed in a port relatively advanced in technology and economy. It differs from other areas due to government's implementation of favoritism and special policies in that area. Such efficacy is economic like other foreign nations' "Free Trade Zone", "Export Processing Zone", and others that all possess the four functionalities of international trade, modern logistics, entry processing, and commodity marketing.

The biggest advantage of bonded area is drastically simplified export-import customs clearance and favorable customs process, and includes other advantages including inspection of goods, tax investigations, foreign exchanges, financial management, etc. that are administered at once. These factors provide accelerated administration of customs procedure and effective business affairs, form ideal investment environment for internationalization of companies, and reduce distribution costs.

The Chinese government, following the successful management of bonded area and BLP, is now focusing on establishing the final directing point of the Free Trade Zone. On September 29th, 2013 the "Shanghai Free Trade demonstration borough" was officially launched to form the progressive economic system more efficient than the traditional system. Likewise, we should take advantage of such BLP to export agricultural processed goods, equipment and materials to solidify Korea's agricultural position there. The trade that utilizes BLP is still mostly conducted by focusing large corporations' products, and in practice, there have been little discussions of agriculture on the surface aside from the manufacturing industry. However, this venue should serve as appropriate consideration for the sixth industry of agricultural companies, small and medium-sized businesses to take part and form an export path to China's market.
\end{abstract}

Keywords: Bonded Area; Bonded logistics complex; Bonded Port; Comprehensive bonded zones; Customs Inspection and Management Zone; Export-Import Procedure;

\section{INTRODUCTION}

After the Chinese Economic Reform (1978), foreign trade expanded dramatically. Total trade value was approximately 20.6 billion dollars (\$B) in 1978 and about 3.96 trillion dollars (\$T) in 2015, or 192 times when compared to the previous year. China in 2015 
was the first in the world for export value and second in import value, making China the leading global trading nation.

China established bonded areas to expand intermediate trading and foreign investment. Recently, China's bonded area business combined physical commerce and e-commerce market to form 'win-win' model for two or more participating countries. 'Bonded' is a Customs terminology defined as 'withholding customs collection for import goods for certain periods' and such practice was the outcome of instilling trade convenience by the Customs agency.

Research on the topic increased as China's bonded area management and establishment expanded after the 1990s. The preceding research on bonded area showed that in 1994 National Bonded Areas Committee, bonded area is defined by bonded warehouse, export processing zone, free trade area (FTA), etc. These methods and areas formed the basis for a new free trade policy. The original planning of China's bonded area development began with efforts to reform standard environments and foreign investments with emphasis on special conditions of Customs and bonds (import tax). Utilizing such mechanics can bring about maximum benefits in foreign capitals and technology that can eventually lead into domestic growth. Therefore, he argued that bonded area's open-door policy is naturally leading the regional economic development as new growth engine. Seo Jeong Cho (2012) argued the performance settings and management policy of China's bonded areas have distinct differences when compared to free trade area (zone). The mutual methodology was used when comparing the development process regulations, functions, characteristics, and etc. Li Li explained that bonded warehouse and bonded factories were the initial steps that convert bonded areas into free trade areas, and as such can be explained to be the first stage of development process. Chen Zhang xi (陈章喜, 2002) when explaining bonded areas' bonded warehouse and bonded industrial areas, and with the exclusion of customs duty levied within China's domain and Customs office, he named these areas a special economic zone. Liu Zhuren(刘助仁, 1995) categorized intermediary trade, export processing, product display, bonded warehouse, banking service, etc. of ten different kinds per function/role. Zhang Feng qing (张凤清, 1996) suggested that selection of bonded warehouse should be chosen by bonded area's present conditions and apply appropriate functions to them. He explains such measures are necessary to avoid promotion of duplicate functions to form bonded warehouse of the highest competitiveness that factor in international, specialization, service, cooperation, and actual practices performed on-site. Zheng Deyan ( 郑德雁, 2002) suggested China's first setting of functions for bonded areas where storage, intermediary and processed trading, which led to post-1988 distribution deployment system should be the major task to be practiced.

Bonded areas are usually established in port areas that have ideal trade environment and as it follows, comparatively well advanced and economically superior area currently benefits along with other areas, appropriate benefits and favoritism. International trading, modern distribution (system), processing at port of entry, product promotion and sales, are four factors that make up typical 'Free Trade Zone' and 'export processing area', etc. The economic effects are similar in this regard.

The biggest advantages for bonded areas are it can drastically reduce the import and export procedure at Customs and benefits in tax clearance. This means that special inspection applied to product investigation (Inspection), duty tax, foreign exchanges, banking services etc. is provided at once thereby reducing Customs procedure. The workload for Customs Office is also reduced and this is helping tasks be more optimized and allow companies to become global through formation of ideal investment environment as well as reducing distribution fees.

China's greatest industrial city in the 
Northwest region, Gansu and regional capital Lanzhou is famous for agricultural processed goods inside the new and comprehensive bonded areas. Within the area, the latest digital information, high tech equipment manufacturing, bio-medicine, and agricultural product processing are central to its economy. Dalian's bonded area is fourth largest in china in trade volume next to Shanghai, and the area is established in the new city's canter. Bonded warehouse, distribution port for cars, processing industries (factories), international shipping and distribution, etc. all have valid business licenses and rights.

These standard bonded areas have formed main driving force behind economic development in export volume. However, now the drastic changes wrought by bonded areas will soon bring about radical changes within domestic markets that are being promoted as policy that can drastically improve and expand current Chinese economies.

Furthermore, continually increasing direct sales of international goods and Chinese tourists' interests in shopping globally has provided us (Koreans) with great opportunity to expand into China's domestic markets. Such factors are considered by the China's government so that Chinese people reduce their foreign expenditure and instead try expanding local and domestic economics through public policy, which has thus far promoted formation of various bonded areas.

The vast majority of markets are placed away from city center area and instead have been placed in outskirts netting poor results. China's government therefore promoted formation of 8 new testing sites for bonded areas in Central China, Shanghai, and other major cities to promote growth in business. The goods sold in these locations all have duty free shopping available, and as such are exempt from import tax and VAT (Valueadded Tax). The duty exception is based per commodity and below certain price, and these products are sold at duty-free.

For example, Korea's cosmetic goods are sold in China through standard distribution paths, and they are sold at 1.5 times the regular price in Korea. However, within bonded areas, these goods can be sold at similar price to prices within Korea. Additionally, food products and cosmetics can both be sold at little regulation or customs measure and they typically do not experience inspection for safety, and these factors provide great opportunities for small to medium businesses to develop export path into China and enter its markets.

Chongqing city established its bonded area in July 2014 within Chéng Squares. Within these designated areas special buildings are permitted as bonded warehouse business, allowing for sales of duty free shopping, a first in China.

It has already been 20 years since China began operating various bonded areas. By the end of 2015, at each regions' bonded area, export processing area, Bonded logistics complex, bonded port area, international industry district/area, etc. made up six different categories of 110 bonded import-export areas. Bonded areas, bonded ports, Bonded logistics complex, regional bonded areas all perform the functions of device, manufacturing, processing, etc.

This study observed prominent theories and current structure's actual conditions on China's bonded areas to highlight its practices and influences. This is to better help extend information on agricultural export from Korean which in turn, should help its viability. The resulting study is also significant with regard to its planning and resulting progress thereby providing relevant information and observes actual facts on-site.

Furthermore, to export at highest efficiency while also remaining within the confines of laws and regulations, we find that seeking solutions within these areas to be the most effective. These methods are, to enter more easily into China's markets, reduction of import tax or exemption through bonded areas, and reduction of export processing China. Such finds should allow for feasible plans to 
develop export pathways into China.

Therefore, the composition of this study is as follows: The second chapter explains structure of bonded areas and distribution policies. The third chapter explains bonded areas by its forms and functions and how it applies in the field. The fourth chapter

\section{MATERIAL AND METHODS}

Our methodology mainly consists of the two parts, such as Bonded Area s and Distribution Policy Comparison and Bonded Area per functions, Forms and Current Affairs. The first method shows the background, characteristics, benefits, and comparison between Bonded Area and Area Distribution Policy. The second one explains the functions, the forms, and the current affairs of Bonded Area. In detail, we explore the current status of bonded areas, i.e., Bonded Areas, Bonded Logistic Complex, Bonded Ports, and Comprehensive Bonded Areas. In general we focus on the applicable empirical research utilizing China's Bonded Areas to expand Korea's agrifood export.

\section{Bonded Areas and Distribution Policy Comparison}

\subsection{Bonded Area \\ a. Background}

China's bonded Area was established in 1990 by the State Council's order and starting with Shanghai Waigaoqiao Free Trade Zone (FTZ), fifteen areas were established throughout China.

Within bonded areas, many productionoriented companies, service industry, and trade companies are located. This is the result of foreign trading companies formed before June 2004 but was never officially recognized by China. Since the introduction of bonded areas, these existing companies proved to be both feasible and officially recognized. Therefore, before the establishment of bonded areas, trading companies could not obtain domestic distribution license or trading rights, summaries previous two chapters to draw plans for direct export into bonded areas with consideration of Chinese laws and regulations. The fifth and final chapter establishes the summary of this study and conclusion with insights into future prospects.

but after July 2005, trading companies within bonded areas could invest with foreign funds by integrating itself to domestic commercial districts with added benefits of obtaining permit for local distribution and trading rights within these areas. This contributed greatly towards the formation of many commercial businesses that characterized bonded areas by its extensive trading and investment opportunities (张毅, 2008).

China used the same plans of bonded areas to maintain foreign investments while also developing its economy to its fullest. Bonded areas operate on forms like bonded area, export processing area, Bonded logistics complex established in 2004, etc. and the most notable is the distribution centers that are specialized in the areas of distribution of goods. These centers main advantages are once goods reach their destination inside China's centers, they are considered imported goods (Export from Korea's point of view, [P.O.V.]) which allows sellers to both receive goods and apply for VAT. Therefore, customs procedure can be simplified while also being located entirely within the port area so there's greater convenience to international shipping and intermediary.

By utilizing these characteristics, the foreign distribution companies can make base of operations inside the distribution centers, and perform international shipping, transfer, and resales, etc. to form sustainable international distribution model. The Chinese government 
also is directly implementing policies aimed at developing these distribution centers as hub of international shipping and domestic distribution network. Such political support has steadily expanded use of distribution centers and such factors are notable for its improving state of China's distribution services.

\section{b. Bonded Areas Characteristics}

Bonded Areas in general have favorable trading environment that allow for relatively technologically advanced ports and in possession of strong economic sectors. They are mostly located in port areas and similar policy to other region is applied to this area. China's bonded area is like other nations' "free ports", "Free Trading Zone (FTZ)", "Export Processing Area", etc. regarding its economic effects. The common similarities are duty exemption and free imports and exports of goods. 'Duty-free' policy allows for foreign companies to both trade and process goods within bonded areas to offset duties imposed on imports and exports traded within the area.

'Free import and export' allow for goods traded within bonded areas to be exempt from taxes and surveillance for inspection. Thus, the 'national surveillance policy' do not apply to imports and exports within the area. This greatly reduces import and export procedures and simplified tax codes.

\section{c. Benefits of Bonded Areas}

The prime benefits of bonded areas include first, duty exemption and VAT exception. The initial fees for construction, import fees for delivering machines, company cost for personal use and production, management, and other fees, construction material fees and fuel costs, and installation materials can all be exempt from tax as long as not explicitly stated by the customs. The company then can import any materials, parts, packaging materials, and packages that are then used for processing or production of export goods, such costs can be exempt from tax. Even if the materials or exports that are considered levied by the law can be except if they are then processed for export, re-exported or imported.

Second benefit comes from exception arising from imported goods and foreign goods within bonded areas used to construct machines, foundation materials, etc. can all be considered free of tax in the case for purposes of re-export and thus exempt.

Third benefits are the formation of trading companies from foreign nations within bonded areas. The businesses can then re-export goods, allow for intermediate service, and perform trade services to others. The deliveries made in between bonded areas are considered imports and exports so the companies within bonded areas supplying other companies in bonded areas can then request for refund of fees involved in the process like VAT. Furthermore, intermediate goods stored in bonded warehouse are first approved by the customs that are then categorized by commodity, precedence, logo-application, printing and packaging of final products; these can also be traded to provide simple process procedures but in practice processing work is impossible during this process.

\subsection{The Comparison of Bonded Area to Area Distribution Policy}

The differences between bonded areas and non-bonded areas' distribution policies can be categorized by their applicable commodity, shelf-life, status of processing, collection of taxes, import and export procedures, after service of exports, etc. are represented in Table 1. 
Table 1. Comparison between Bonded Areas and Non-Bonded Areas

\begin{tabular}{|l|l|l|}
\hline & \multicolumn{1}{|c|}{ Bonded Distribution Policy } & \multicolumn{1}{c|}{ Non-bonded Dist. Policy } \\
\hline Applicable & $\begin{array}{l}\text { With exception of outlawed products for } \\
\text { import, all products traded from foreign } \\
\text { sources can be stored within bonded area. }\end{array}$ & $\begin{array}{l}\text { Normal trade goods or forbidden } \\
\text { goods cannot be imported, and such } \\
\text { products cannot be stored within } \\
\text { bonded areas }\end{array}$ \\
\hline Timeframe & $\begin{array}{l}\text { No set rules exist for commodity storage } \\
\text { timeframe and no existing regulation is in } \\
\text { force }\end{array}$ & $\begin{array}{l}\text { The storage time for all commodity is set } \\
\text { to maximum of one year and any leftover } \\
\text { products after must be returned to sender } \\
\text { country or destroyed }\end{array}$ \\
\hline Processing & $\begin{array}{l}\text { Goods stored within bonded areas can un- } \\
\text { dergo commercial processing tasks (Pack- } \\
\text { aging, labelling, individual packaging, } \\
\text { maintenance work, etc.) can be performed } \\
\text { and maintain its initial country of origin }\end{array}$ & $\begin{array}{l}\text { Goods stored within bonded areas } \\
\text { cannot be processed in any way }\end{array}$ \\
\hline Tax Code & $\begin{array}{l}\text { Imported goods can be stored within bond- } \\
\text { ed areas without the needs for permits, } \\
\text { and no additional tax is charged. Good } \\
\text { stored in bonded warehouse do not need } \\
\text { evidence(papers) for transportation into } \\
\text { foreign nations, no tax is incurred, and only } \\
\text { need to clear the import/export customs pro- } \\
\text { cedures }\end{array}$ & $\begin{array}{l}\text { Foreign goods stored in bonded ware- } \\
\text { house are categorized as imported } \\
\text { goods and tax is applied. Import } \\
\text { Permit is required. To store goods in } \\
\text { bonded warehouse, goods need to go } \\
\text { through custom's clearance on im- } \\
\text { port/export procedures }\end{array}$ \\
\hline $\begin{array}{l}\text { Domestic goods (Tertiary companies' com- } \\
\text { pleted products are included) transported } \\
\text { into bonded area is determined to be export } \\
\text { and this can be later processed easily as ex- } \\
\text { port. }\end{array}$ & $\begin{array}{l}\text { Domestic goods bound for export can } \\
\text { be stored in the export control and } \\
\text { inspection warehouses. Completed } \\
\text { products of tertiary companies need } \\
\text { to export via ships so as to complete } \\
\text { it's after service tasks. }\end{array}$ \\
\hline After Service
\end{tabular}

Source: "Current Affairs and Growth in China's Bonded Areas", Incheon Development Institute, 2010.

\section{Bonded Areas per Functions and Forms and Current Affairs}

\subsection{Bonded Areas Functions}

Since 1980s bonded areas were limited to simply for storage of district processing trade materials, on demand sales, maintenance of sales, etc. which are limited to simple functions. However, on June 1990, China's plans for foreign trading changed to instead develop intermediate trades by establishing Shanghai Waigaoqiao FTZ(浦东外高桥), first bonded area (S. W. FTZ United Development
Co, LTD, 2005). Currently, China's bonded areas primarily manage functions of bonded distribution, international trading, bonded processing, etc. In its inception the area's function was primarily for international trading. However, as of now, the functions have been reinforced with features of processing industry, distribution warehouses, etc. These functions can be divided into forms of tradeoriented bonded area, processing-oriented bonded area, and general-use bonded area. 
Table 2. Functions in the bonded areas in china

\begin{tabular}{|c|c|c|}
\hline & Bonded Area & Primary Functions \\
\hline \multirow{8}{*}{$\begin{array}{l}\text { General Purpose } \\
\text { Bonded Area }\end{array}$} & Dalian(大连) & $\begin{array}{l}\text { International Trading, Distribution Warehouse, Product } \\
\text { Display, Export Processing }\end{array}$ \\
\hline & Qingdao(青岛) & $\begin{array}{l}\text { International Trading, Bonded Warehouse, Cargo Extraction, } \\
\text { Import and Export Processing, Product Display }\end{array}$ \\
\hline & $\begin{array}{l}\text { Zhangjiagang (张 } \\
\text { 家港) }\end{array}$ & $\begin{array}{lccc}\text { International Trading and Product Display, Bonded } \\
\text { Warehouse, Export Processing }\end{array}$ \\
\hline & $\begin{array}{l}\text { Shanghai } \\
\text { (上海外高橋) }\end{array}$ & $\begin{array}{l}\text { International Trading, Bonded Warehouse, Distribution } \\
\text { Centers, Bonded Products Trading Displays, Export } \\
\text { Processing }\end{array}$ \\
\hline & Ningbo(宁波) & Export Processing, International Trading, Bonded Warehouse \\
\hline & Shenzhen(福田) & High-Tech Industry, Modern Distribution \\
\hline & $\begin{array}{l}\text { Guangzhou } \\
\text { (广州) }\end{array}$ & $\begin{array}{l}\text { Processing Trading, Shipment } \\
\text { Distribution, Bonded } \\
\text { Warehouse, International Service Trading, Product Display }\end{array}$ \\
\hline & Zhuhai(珠海) & Export Processing, Bonded Warehouse, International Trading \\
\hline \multirow{3}{*}{$\begin{array}{l}\text { Process-oriented } \\
\text { Bonded Area }\end{array}$} & $\begin{array}{l}\text { Shenzhen } \\
\text { (沙頭角) }\end{array}$ & Outbound Export Processing Companies \\
\hline & Shantou(汕头) & Processing Composition \\
\hline & Haikou(海口) & Export Processing, International Trading \\
\hline \multirow{4}{*}{$\begin{array}{l}\text { Trade-oriented } \\
\text { Bonded Area }\end{array}$} & Tianjin(天津) & International Trading, Modern Distribution, Product Display Sales \\
\hline & Fuzhou(福州) & $\begin{array}{l}\text { International Distribution, Bonded Warehouse, International } \\
\text { Trading }\end{array}$ \\
\hline & Xiamen(厦门) & Bonded Warehouse, Cargo Extraction, Service Trading \\
\hline & Shenzhen(鹽田) & $\begin{array}{l}\text { International Distribution, International Purchasing, } \\
\text { International Trade Intermediate }\end{array}$ \\
\hline
\end{tabular}

Source: “中国保税区的功能转型与发展的思考一基于上海外高桥保税区的案例分析”, 2007; Incheon development institute, 2010.

\subsection{Current status of bonded area a. Bonded Area}

China since end of 1996 have designated Shanghai(上海), Tianjin(天津), Liaoning( 辽宁), Shandong(山东), Jiangsu(江苏), Zhejiang(浙江), Fuzhou(福州), Guangdong( 广东), Hainan(海南), etc. 15 regions, the total area is $41.32 \mathrm{~km}$ squares.
All bonded areas are located in the port city of coastal regions, and Shanghai's port is largest at $10 \mathrm{~km}$ squares. As for, Shenzhen(沙 頭角) regions bonded area is smallest at 0.37 km squares.

Guangdong Province (6), Shenzhen City (3), Fujian Province (2), In addition, there are free trade zones in 4 regions. 
Table 3. Current status of bonded areas (15 City) designated by the state

\begin{tabular}{|l|l|c|c|c|c|}
\hline № & \multicolumn{1}{|c|}{ Name } & Established & Closure & Area $\left(\mathrm{km}^{2}\right)$ & Closed Area $\left(\mathrm{km}^{2}\right)$ \\
\hline 1 & Shanghai(上海外高橋) & 1990.6 & 1991.12 & 10.00 & 8.50 \\
\hline 2 & Tianjin(天津) & 1991.5 & 1992.4 & 5.00 & 3.80 \\
\hline 3 & Shenzhen(沙頭角) & 1991.5 & 1992.9 & 0.37 & 0.27 \\
\hline 4 & Shenzhen(福田) & 1991.5 & 1993.2 & 1.68 & 1.35 \\
\hline 5 & Dalian(大连) & 1992.5 & 2000.4 & 1.95 & 1.95 \\
\hline 6 & Guangzhou(广州) & 1992.5 & 1993.5 & 2.00 & 2.00 \\
\hline 7 & Haikou(海口) & 1992.10 & 1993.4 & 1.93 & 1.93 \\
\hline 8 & Xiamen(厦门) & 1992.10 & 1993.11 & 1.50 & 0.63 \\
\hline 9 & Zhangjiagang(张家港) & 1992.10 & 1993.4 & 4.10 & 4.10 \\
\hline 10 & Ningbo(宁波) & 1992.11 & 1993.2 & 2.30 & 2.3 \\
\hline 11 & Fuzhou(福州) & 1992.11 & 1993.1 & 1.80 & 0.80 \\
\hline 12 & Qingdao(青岛) & 1992.11 & 1993.3 & 2.50 & 2.50 \\
\hline 13 & Shantou(汕头) & 1993.1 & 1993.12 & 2.34 & 2.34 \\
\hline 14 & Shenzhen(盐田) & 1996.9 & 1999.1 & 0.85 & 0.85 \\
\hline 15 & Zhuhai(珠海) & 1996.11 & 1999.5 & 3.00 & 3.00 \\
\hline
\end{tabular}

Source: 中國保稅區出口加工協會，「中国保税区出口加工区年鉴」，中国海关出版社，2010.

\section{b. Bonded logistics complex (保稅物類團地)}

Bonded Areas established outside of port areas do not feature tax converted for export, so even if the goods are exported, fees cannot be refunded later. Also, due to rate of globalization trends accelerating, these areas are inadequate to function with all the features of China's economic growth, thus Bonded logistics complex like port-connection was established.

The Bonded logistics complex are connected to ports via regional connections. The functions of storage and coastal areas' shipping function were combined to form 'Nine harbor bodies' (區港一體)' within the bonded areas and specialized harbor area. These complex in between ports are under special jurisdiction of related institution.

China with the approval of the state council established 10 Bonded logistics complexes spread around in mainland China, totaling 9.66 $\mathrm{km}$ squared. By the end of 2007, 8 Bonded logistics complexes of China had 601 different businesses operating within the area and the investment reached $\$ 1.11 \mathrm{~B}$.

Table 4.Current status of bonded logistics complex designated by the state

\begin{tabular}{|c|l|c|c|c|}
\hline № & \multicolumn{1}{|c|}{ Name } & Established & Area $\left(\mathrm{km}^{2}\right)$ & Closed Date \\
\hline 1 & Shanghai (上海外高橋) & 2003.12 & 1.02 & 2004.4 \\
\hline 2 & Tianjin(天津) & 2004.8 & 1.50 & 2005.3 \\
\hline 3 & Shenzhen(盐田) & 2004.8 & 0.96 & 2005.12 \\
\hline 4 & Dalian(大连) & 2004.8 & 1.50 & 2004.11 \\
\hline 5 & Qingdao(青岛) & 2004.8 & 1.00 & 2005.11 \\
\hline 6 & Ningbo(宁波) & 2004.8 & 0.95 & 2005.8 \\
\hline 7 & Zhangjiagang(张家港) & 2004.8 & 1.53 & 2005.1 \\
\hline 8 & Xiamen(厦门) & 2004.8 & 0.70 & 2006.3 \\
\hline 9 & Ghuangzhou(广州) & 2007.12 & 0.50 & 2008.12 \\
\hline 10 & Fuzhou(福州) & 2008.1 & 1.20 & 2008.7 \\
\hline
\end{tabular}

Source: 中國保稅區出口加工協會, 「中国保税区出口加工区年鉴」, 中国海关出版社, 2010. 


\section{c. Bonded Port}

Bonded port with the approval of the State Council had established specialized zone for foreign trades and export towards other nations. Within these area is the designated zones for port, distribution, processing, etc. functions for Customs duties.

Bonded port combines the functions of bonded area, Bonded logistics complex, and export processing zone while also addressing issues inherent to those functions. The "Nine
Port One Body” (區港一體)was fully realized to provide unique functions different to other bonded areas.

Observing these functions, one can find the functions of distribution warehouse, foreign trading, international buying and selling, delivery services, inspection and holding areas, commodity display, $\mathrm{R} \& \mathrm{D}$, processing and composition (production), port duties, etc. to form 8 different functions.

Table 5. Current status of bonded ports designated by the state

\begin{tabular}{|c|l|c|c|}
\hline \multicolumn{1}{|c|}{ № } & \multicolumn{1}{|c|}{ Name } & Established & Planned Area $\left(\mathrm{km}^{2}\right)$ \\
\hline 1 & Shanghai(上海外高橋) & 2005.6 & 8.14 \\
\hline 2 & Tianjin(天津) & 2006.8 & 10.0 \\
\hline 3 & Dalian(大连大窯湾) & 2006.8 & 6.88 \\
\hline 4 & Hainan(海南洋浦) & 2007.9 & 9.21 \\
\hline 5 & Ningbo(宁波梅山岛) & 2008.2 & 7.70 \\
\hline 6 & Guanxi Qinzhou (广西钦州) & 2008.5 & 10.0 \\
\hline 7 & Xiamen(厦门海沧) & 2008.6 & 9.45 \\
\hline 8 & Qingdao(青岛前湾) & 2008.9 & 9.72 \\
\hline 9 & Guangzhou (广州南沙) & 2008.10 & 7.06 \\
\hline 10 & Shenzhen(深圳前海湾) & 2008.10 & 3.71 \\
\hline 11 & Chongqing(重庆两路寸滩) & 2008.11 & 8.37 \\
\hline 12 & Zhangjiagang(张家港) & 2008.12 & 4.10 \\
\hline
\end{tabular}

Source: 中國保稅區出口加工協會, 「中国保税区出口加工区年鉴」, 中国海关出版社, 2010.

\section{d. Comprehensive bonded zones}

Comprehensive bonded zones are a form that combines all the policies of Customs special areas that include bonded areas, export processing area, distribution centers' functions.

Comprehensive bonded zones perform 'bonding' within the confines of its mandate on any foreign goods transported. Any goods passing through the area can be regarded as China's domestic goods and benefit from tax redemption later as export goods.

Business within Comprehensive bonded zones can perform tasks of foreign trading, composition, processing and make use of bonded warehouse.

Table 6. Current status of Comprehensive bonded zones designated by the state

\begin{tabular}{|c|l|c|c|}
\hline № & \multicolumn{1}{|c|}{ Name } & Established & Planned Area $\left(\mathrm{km}^{2}\right)$ \\
\hline 1 & Suzhou(苏州) & 2005.6 & 8.14 \\
\hline 2 & Tianjin(天津滨海新区) & 2006.8 & 10.0 \\
\hline 3 & Beijing(北京全球) & 2006.8 & 6.88 \\
\hline 4 & Haikou(海口) & 2007.9 & 9.21 \\
\hline 5 & Guangxi(广西凭祥) & 2008.2 & 7.70 \\
\hline
\end{tabular}

Source: 中國保稅區出口加工協會, 「中国保税区出口加工区年鉴」, 中国海关出版社, 2010. 


\section{RESULTS}

\section{Bonded Area Export Plan \\ a. Bonded Stocks}

Bonded stocks refer to sellers storing their goods within Bonded logistics complex and selling it to domestic consumers on demand. This method allows the goods to be sold only when it is necessary. Goods going through Customs on a small scale for multiple times at the distribution center can be except should the sellers get an approval from the relevant Customs. Customs fee can be reduced (Multiple Customs procedure and tax on remaining stock, etc.) to benefit the customers and through reduced transportation time, the sellers can react to multitude of orders that are small in monetary value.
Domestic market in china

\section{Bonded logistics complex}

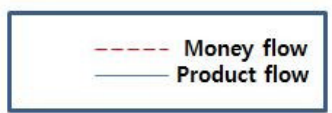

Overseas

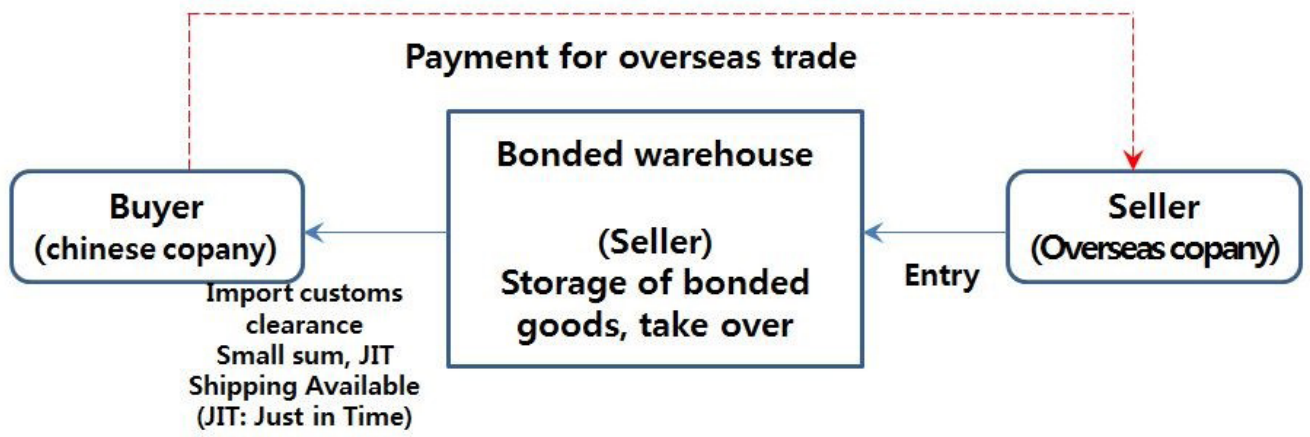

Figure 1. Export Plan through China's Bonded Area A

Source: Ministry of Economy, Trade, Industry, japan (METI) "Trade White Papers, 2007"

\section{b. Buyer's Consolidation}

Buyer's consolidation refers to foreign buyers requesting goods from China's sellers of Bonded logistics complex and its inclusive benefits, and goods are exchanged. These goods are stored in Bonded logistics complex and after repackaging, goods are sent to foreign nations on a need to need basis. Buyers by utilizing China's Bonded logistics complex can store goods within the warehouse at a cheaper rate than in Japan, Hong Kong, and Taiwan's warehouses. And for Chinese consumers faster tax redemption and benefits, and reduced processing times are mutually beneficial to both parties.

\section{c. International Import and Export Trading}

International trading involves foreign business A's buyer imports goods from
Chinese business B's sellers on the condition that Bonded logistics complex be utilized. This arrangement involves storing imported goods within Bonded logistics complex for the purposes of storage and repackaging work, and then exported again to China's Business C. At Bonded logistics complex, tertiary business $\mathrm{C}$ buys the goods from the warehouse. During this process, Logistic Centers, Warehouse Company, and foreign business all collaborate on the basis of goods request contracts and pertaining foreign currency exchanges. Thus, commodity transportation and processing can all be done within China, yet foreign currency can be used to pay for services. In practice, this reduced transportation time and fees can benefit more so than conventional processing trade. 


\section{Domestic market in china}
Bonded logistics complex

Overseas

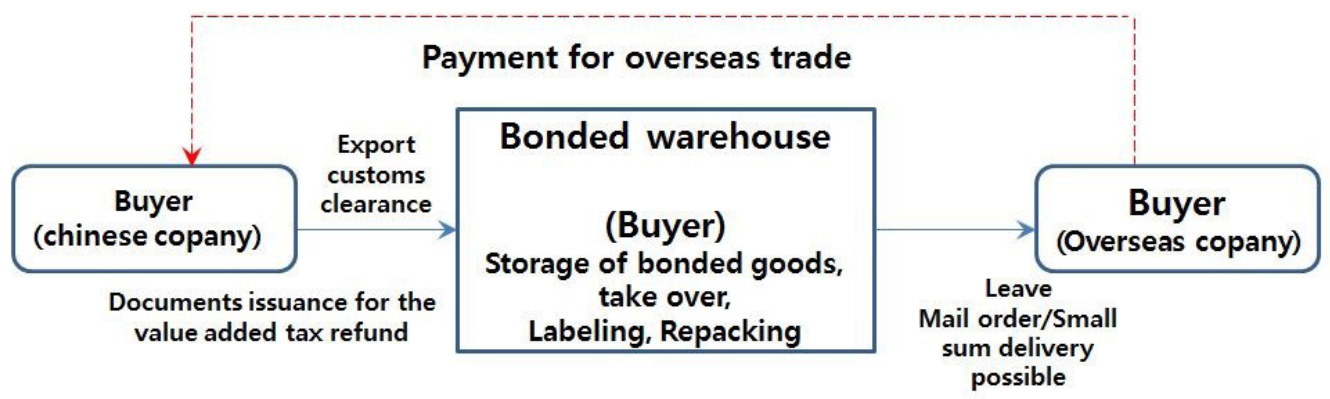

Figure 2. China's bonded Area Export Plan B

Source: METI 'White Trade Papers 2007'

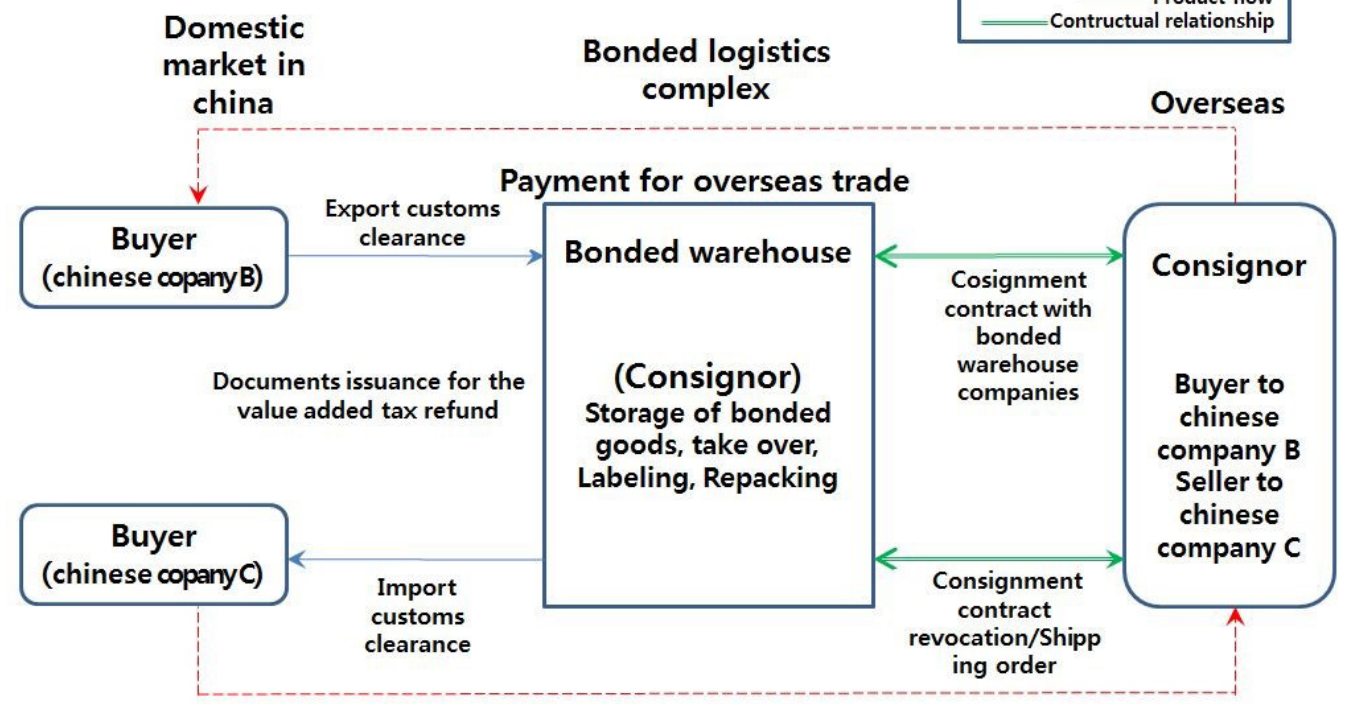

Figure 3. China's bonded area Export Plan C

Source: METI "Trade White Papers 2007"

The three methods recommended above all utilize China's bonded areas to help Korea's agricultural export. And out of three, utilizing Bonded logistics complex seem most promising.

China's Bonded logistics complex along with other bonded areas can be highly beneficial in the sense of sustainable domestic regulations and policy performance. However, the Bonded logistics complex are yet to be utilized uniformly across all regions, and each Bonded logistics complex have its 
unique policy and management. This is an inconvenient fact but by carefully adhering to dangers ahead, above plan can be strategically employed to reduce costs and enter into China's market. This factor can definitely help Korea's agricultural produce enter China's market and still maintain its economic edge.

Now, China's government following the successes of bonded areas and Bonded logistics complex is now looking to lead up to final destination of free trade zone creation. On September 29th, 2013, 'Shanghai Free Trade Zone' was officially created to form better and efficient economic systems.

\section{CONCLUSION}

China is showing trends of growth into international economic growth and international trading, which are both positively increasing. Foreign markets have all increased demands and due to continued increases in bonded areas, bonded logistics center, etc. trade value increased is greatly contributing to the China's trade developments.

The majority of bonded areas lack the relevant connections so low-cost and high efficiency distribution service cannot be readily provided. However, on December 12, 2004, Chin's openings of markets have greatly changed the trade patterns of foreign corporations and triangle trading has taken place as a large factor. This is in sharp contrast to its pertaining problems, but it is still a refreshing characteristic of bonded areas when compared to before.

Past bonded area policies' weakness can be said to be even if the goods are imported into bonded areas, if the goods are not exported into China's domain at its final stage, it cannot be accepted as export. This means that the goods cannot benefit from tax exemptions in increased sales value, commodity value increased and etc. tax benefits. This also means that distribution problems within bonded areas and difficulties in foreign currency exchanges.

Therefore, a unified system of bonded
We found these advantages of Bonded logistics complex and thus export Korea's agricultural products and materials into China. This will increase the recognition of Korea's products worldwide. However, businesses that utilize bonded distribution centers are mainly large corporations' products, so in practice, agricultural products have not net any results nor have been reported widely. However, agricultural companies, businesses, and other 6th industry small and medium businesses area are suitable candidates for forming initial lines of export into China.

area's Yuan currency exchanges should be constructed to perform collection, conversion, exchanges, supply, etc. duties at the central banks and respective nations tax codes. The focus should be placed into management, maintenance, etc. bonded area reforms.

China's government should reform the limits of bonded areas, and implement advanced nations distribution methods to specially admit certain areas. The generalized 'bonded distribution centers' can perform all necessary bonded area duties and distribution functions. These places perform duties of warehouse, distribution, and intermediary services to try forms that focus on the distribution. 'bonded distribution logistics center's areas are regarded as 'foreign nation', thus China's domestic areas entering this area are considered export, and VAT can be applied, differentiating itself from other bonded areas.

Importing goods from foreign nations into Bonded logistics complex imply that goods will be declared within 15 days to the Customs, and report its import declaration forms. However, Bonded logistics complex are exempt from such responsibilities. Afterwards, this area when importing goods from other areas, import declarations can be made, and if the goods are bound to tertiary country for the purposes of export, delivery request can be made to export, 
which is great for intermediary services.

However, this study focuses on the utilization of bonded areas for Korea's agricultural produce. Therefore, the topics of development paths or buyer-matching were not listed as second or third export planning. Currently, even if there is an export path from Korea to other nations, the warehouses that can be supplied with our goods are limited, and when time and economy are factored in, they themselves become limiting to the Korean businesses. Therefore, export should be focused by introducing bonded areas with features of storage and processing to form sustainable and safe export paths. In order to export into China's bonded areas, sufficient knowledge and ample preparations are needed, and this includes thorough investigation on-site to understand relevant laws and perform duties of contractual obligations and regulations

Moving forward, China's bonded areas will continue to develop and grow. Korea's agriculture should follow such developments to create custom products fit to such specifications, high quality and price production's R\&D implementations to lead into high quality, environmentally friendly, and modern design researches that all contribute to exporting into China for the near future. 


\section{REFERENCES}

1. Buk-Kyung Office, (KIEP), China's Economic Affairs Briefing, 2014.

2. Cho Seo-Jeong, "A Study on China's Bonded Areas' Management and Development plan", SIlla University, Master's Degree Research, 2012

3. Hwang Hyun-Ju, "Analysis of Distribution Service per China's Public Policy and Reforms, and its Outlying Effects", 『Korea Information Society Development Institute』, 2015.

4. Ministry of Economy, Trade, Industry, Japan (METI), "Trade White Papers: The strategy for expanding growth into productivity and trading”, 2007.

5. Incheon Development Institute, "Current Affairs and Growth in China's Bonded Areas", 2010.

6. Incheon Development Institute, "Bonded Distribution System, China's Way of Reinforcing Distribution through Use" \#08-02, 2008.

7. ilyo Weekly, “China E-Commerce, Export Market's Infusion into 'Big Bang'”, 2016.

8. Shanghai Waigaoqiao Free Trade Zone United Development Co, LTD, Invest Guide to Shanghai Waigaoqiao Free Trade Zone, 2005.

9. 李力, “加入WT0后如何打造中国的自由贸易区” , 『世界贸易组织动态与研究』, 第9期, 上海对外贸易学院, 2001, pp. 13-16.

10. 李嵐清, “中国利用外资基础知识”，1995，pp. 35 .

11. 陈章喜, “中国 “入世” 后保税区的功能调整与体制转换”，『国际贸易问 题』，第4期，对外经济贸易大学，2002，pp. 13-15.

12. 刘助仁，“中国保税区及其发展构想”，『国际贸易问题』，第9期，对外经济 贸易大学, 1995, pp.17-21.

13. Use the "Insert Citation" button to add citations to this document.

14. 林康. 尤崧涛, “论世界自由贸易区与我国保税区的功能和作用”，『国际贸易 问题』，第3期，对外经济贸易大学，2000，pp. 34-37.

15. 张毅, “我国保税区发展趋势与对策的研究”, 厦门大学, 硕士学位论文, 2008, pp. 4-5.

16. 张凤清, ” 关于中国保税区发展的若干问题思考”，外国经济与管理，第2期，上 海财经大学, 1996, pp. 3-7

17. 郑德雁，“保税区功能 该如何认定位”，『中国统计』，第2期，国家统计局, 2002, pp. 25-28.

18. 孙敏, “中国保税区的功能转型与发展的思考一基于上海外高桥保税区的案例分 析”，上海外国语大学，硕士学位论文，2007.

19. “中国保税区出口加工区年鉴” , 「中国海关出版社」, 2010, pp. 320-326.

20. “上海国际上海经济发展报告”，「上海蓝皮书」，2013.

21. “中华人民共和国海关对报税物流园区的管理办法”，「海关总署令」，2005， 第134号. 